Open ACcess

EDITORS

- Miguel Oliveira Jr. (UFAL)

- René Almeida (UFS)

REVIEWERS

- Cândido Oliveira (CEFET-MG)

- Adan Phelipe Cunha (USP)

ABOUT THE AUTHORS

- Aleksandra S. SKOROBOGATOVA Data Curation, Investigation, Writing - Original Draft.

- Anna Smirnova Henriques Data Curation, Investigation,

Visualization, Writing - Original Draft.

- Svetlana Ruseishvili

Writing - Original Draft.

- Irina A. Sekerina

Conceptualization, Methodology,

Writing - Review, Editing.

- Sandra Madureira

Project Administration, Supervision, Writing - Original Draft - Review, Editing.

DATES

- Recebido: 20/08/2021

- Aceito: 23/09/2021

- Publicado: 17/11/2021

HOW TO CITE

SKOROBOGATOVA, A. S.; SMIRNOVA HENRIQUES, A..; RUSEISHVILI, S.;

SEKERINA, I. A..; MADUREIRA, S. (2021). Verbal working memory assessment in Russian-Brazilian Portuguese bilinguals. Cadernos de Linguística, v. 2. n. 4, e572.
PILOT STUDY

\section{VERBAL WORKING MEMORY ASSESSMENT IN RUSSIAN-BRAZILIAN PORTUGUESE BILINGUALS}

\author{
Aleksandra S. SKOROBOGATOVA (iD $\boldsymbol{D}$ \\ Universidade de São Paulo (USP)
}

Anna SMIRNOVA HENRIQUES (iD $\boldsymbol{M}$

Pontífícia Universidade Católica de São Paulo (PUC-SP)

Svetlana RUSEISHVILI iD $\boldsymbol{\Sigma}$

Universidade Federal de São Carlos (UFSCar)

\section{Irina A. SEKERINA (D) $\boldsymbol{x}$ \\ City University of New York (CUNY)}

\section{Sandra MADUREIRA iD $\boldsymbol{\Omega}$ \\ Pontífícia Universidade Católica de São Paulo (PUC-SP)}

\section{ABSTRACT}

In Brazil, the learning of a second language (L2) by speakers of Brazilian Portuguese as a first language (L1) has been extensively explored, but studies on language processing and language interaction among bilinguals are quite recent. The late bilingualism of the first-generation immigrants has been studied mainly from the perspective of their difficulties in learning Brazilian Portuguese. Brazil has numerous communities of heritage speakers of many languages such as Japanese, German, Italian, Polish, Ukrainian, and Russian. However, the number of studies that focus on the bilingual speech of heritage speakers in Brazil is quite limited. The aim of the current study is to assess the working memory in Russian-Brazilian Portuguese bilinguals as a function of the tested language and language dominance profiles. For this purpose, 49 first-generation Russophone immigrants and 28 elderly Russian heritage speakers, all residing in Brazil, were tested in Russian and Portuguese using a Month-Ordering task. We found that 
the working memory scores of the first-generation Russophone immigrants were not statistically different between both languages, but the median working memory score of the elderly Russian heritage speakers in Russian was 1.5-fold lower than in Portuguese. As next steps, we plan to verify the relation between the working memory capacity and narrative production abilities of the elderly Russian heritage-Brazilian Portuguese bilinguals in their heritage and societal languages.

\section{RESUMO}

No Brasil, o campo de aprendizagem de L2 por falantes de português brasileiro como L1 é amplamente explorado, mas os estudos sobre o processamento de linguagem e a interação entre as línguas em bilíngues são bastante recentes. O bilinguismo tardio dos imigrantes de primeira geração é estudado principalmente com foco nas dificuldades de aprendizagem do português brasileiro. O Brasil tem inúmeras comunidades de falantes de herança de várias línguas, como japonês, alemão, italiano, polonês, ucraniano e russo. No entanto, no Brasil, o número de estudos que enfocam a fala de falantes de herança é bastante restrito. O objetivo do presente trabalho é avaliar a capacidade de memória de trabalho em indivíduos bilíngues em russo e português brasileiro e verificar se ela varia em função do idioma testado e do perfil de dominância linguística. Para esse fim, 49 imigrantes russófonos de primeira geração e 28 falantes de russo de herança idosos, todos residentes no Brasil, foram testados em russo e português, por meio da tarefa de organização da ordem de meses. Apontamos que os scores de avaliação de memória de trabalho dos imigrantes russófonos de primeira geração não diferem estatisticamente entre as duas línguas, mas que os scores de memória de trabalho dos falantes de russo de herança idosos em russo se mostraram 1,5 menores do que em português. Nas próximas etapas, pretendemos verificar a relação entre a capacidade de memória de trabalho e o desempenho na produção narrativa dos falantes de russo de herança idosos, bilíngues em português, nas duas línguas.

\section{KEYWORDS}

Bilingualism; working memory; Brazilian Portuguese as L2; heritage Russian; Russophones.

\section{PALAVRAS-CHAVE}

Bilinguismo; memória de trabalho; português brasileiro como L2; russo como língua de herança; russófonos. 


\section{INTRODUCTION}

There are different definitions of bilingualism. Here we follow the definition of bilingualism as the use of two or more languages (or dialects) in everyday life (GROSJEAN; LI, 2013). This definition does not presuppose "native-like" proficiency: the languages can be acquired simultaneously or sequentially, language skills (speaking, listening, reading, and writing) can be unbalanced, the proficiency level and the size of vocabulary in each language may vary in different contexts.

The bilingual profiles of the speakers depend on the language dominance that includes the use of languages across the lifespan, language attitudes, and proficiency as one of its components (BIRDSONG, 2006; BEDORE et al., 2012). This is especially important to discuss in the context of migrant generations. The first-generation immigrants who came to a new country as adults maintain their first language as dominant for the rest of their lives; the next generations acquire the societal language within the primary education system and are considered to be heritage speakers of the language spoken by their parents (ALBA et al., 2002; BAHRICK et al., 1994; CONNAUGHTON-CREAN; Ó DUIBHIR, 2017; PORTES; HAO, 1998; SEVINÇ, 2016).

Heritage speakers represent a special category of bilinguals who were exposed to their first language (L1) at home in the childhood, but later acquired the societal language that became dominant (D'ALESSANDRO; NATVIG; PUTNAM, 2021; CUMMINS, 2005; POLINSKY; KAGAN, 2007). The interference of the societal language on their pronunciation in the heritage language is often not notable, and they have a special phonetic advantage in re-learning the heritage language ( $A U$ et al., 2008; $A U$; ROMO, 1997). At the same time, their vocabulary in $L 1$ is rather limited, and their usage of grammar structures in L1 is generally influenced by transfer from their dominant societal language. Thus, the bilingual heritage speakers represent a very special category of bilinguals to be studied in relation to language processing (D'ALESSANDRO; NATVIG; PUTNAM, 2021; BOLGER; ZAPATA, 2011). The research on heritage speakers can address such issues as the developmental trajectories of heritage grammars across the lifespan as well as the potential universal features and generalizable tendencies of human language (D'ALESSANDRO; NATVIG; PUTNAM, 2021). The studies of elderly individuals who represent the final generation of proficient speakers of a moribund heritage language are of special interest: this unique language material is lost in their next generation.

In Brazil, the learning of a second language (L2) by speakers of Brazilian Portuguese as L1 has been extensively explored, but studies on language processing and language interaction among bilinguals are quite recent (ZIMMER; FINGER; SCHERER, 2008). The late bilingualism of the first-generation immigrants has been studied mainly from the perspective of their difficulties in learning Brazilian Portuguese (SMIRNOVA HENRIQUES; 
BARROS; MADUREIRA, 2020). Brazil has numerous communities of heritage speakers of many languages such as Japanese (ABREU MORATO, 2011; NAWA, 1988); German, including the Hunsrückisch dialect (ALTENHOFEN; MORELLO, 2018; GEWEHR-BORELLA; ZIMMER; ALVES, 2011; KRAMER; MOTA, 2015); Italian, including a north Italian dialect Talian/Venetian (BENINCÁ, 2018; COMIOTTO; MOTA; SOARES, 2020; FAGGION; LUCHESE, 2016); Polish (COSTA; LOREGIAN-PENKAL, 2015; MILESKI, 2017); Ukrainian (COSTA; LOREGIAN-PENKAL, 2015); and Russian (RUSEISHVILI, 2016; VOROBIEFF, 2006). However, the number of studies that focus on the bilingual speech of heritage speakers in Brazil is quite limited (COMIOTTO; MOTA; SOARES, 2020; NAWA, 1988; BORSTEL, 1992).

Our group has recently begun studying the late bilingualism of the first-generation Russophone immigrants in Brazil who arrived from the former Soviet Republics, and characterized special features of their speech in Brazilian Portuguese (SMIRNOVA HENRIQUES et al., 2019; SMIRNOVA HENRIQUES et al., 2020). Our new project aims to characterize the speech of elderly Russian heritage speakers in Brazil who arrived as children in the 1950s or were born in Brazil in Russophone immigrant families that left Russia after the Bolshevik Revolution (SMIRNOVA HENRIQUES et al., 2021). Samples of these bilinguals' speech productions have been collected for the construction of the BraPoRus (Brazilian Portuguese Russian) corpus (SMIRNOVA HENRIQUES et al., 2021). Some additional protocols for the characterization of the language processing by these speakers have been included, for example, the analysis of the narrative abilities in Russian and Portuguese using the MAIN (Multilingual Assessment Instrument for Narratives, GAGARINA et al., 2016) protocol.

Narrative abilities depend on the working memory in both monolingual and bilingual elderly adults (KORMOS; TREBITS, 2011; TSIMPLI et al., 2014; TSIMPLI; PERISTERI; ANDREOU, 2016), hence the necessity to first establish a protocol for the assessment of the working memory capacity. The comparison between the performances on working memory capacity in Russian and Portuguese of the two groups residing in Brazil, the firstgeneration immigrants, dominant in Russian, and the heritage Russian speakers, dominant in Portuguese, also can bring new insights about the relation between working memory capacity and language dominance.

The aim of the current work is to assess the working memory capacity as a function of the tested language and language dominance profiles in two groups of RussianBrazilian Portuguese bilinguals residing in Brazil: (i) the first-generation immigrants who acquired Russian as children, in Russian-speaking homeland, and Portuguese as adults (see Section 1.2) and (ii) the Russian heritage speakers who acquired Russian as children, at home in Brazil or other non-Russian-speaking country, but spent most of their time in Brazil and speak Portuguese as the societal language (see Section 1.1). For this purpose, 49 first-generation Russophone immigrants and 28 elderly Russian heritage speakers, all 
residing in Brazil, were tested in Russian and Portuguese using a Month-Ordering task (GORAL et al., 2011; KEMPLER et al., 1998). The working memory spans were assessed in each group for both languages. Correlations with age and, whenever possible, time of residence were verified

\section{THEORETICAL BACKGROUND}

\subsection{RUSSOPHONE IMMIGRATION WAVES IN BRAZIL IN THE $20^{\text {TH }}$ CENTURY}

Russophone migration to Brazil can be analyzed in four periods (RUSEISHVILI, 2016). The first period, on the turn of the $19^{\text {th }}$ to the $20^{\text {th }}$ century, concerns arrival of the immigrants from the Russian Empire (BYTSENKO, 2006). The Russian German and religious minorities immigrants were farmer families headed for the south and south-east of Brazil as a part of the government campaign for colonization, settlement and branqueamento (whitening policies) of the Brazilian population by the European immigrants. At the beginning of the $20^{\text {th }}$ century, the Russian Jews from the south-east region of the Russian Empire were fleeing from pogroms and discrimination. These immigrants settled in the big cities in the Brazilian South-East, mainly in São Paulo (BLAY, 2013).

The second period lasted from the revolution of 1917 and Russian civil war to the Second World War (RUSEISHVILI, 2016). In 1921, around one thousand stateless refugees, ex-soldiers and military officials of the counter-revolutionary White Army arrived in São Paulo. These people were treated as immigrants and sent to the rural regions for coffee production; however, in a short time, they were emancipated and settled in the big cities, above all, in São Paulo. In the 1920s, the rearrangement of the borders in the Eastern Europe displaced one more immigrant group: Bessarabian peasants. Between 1920 and 1927, around 29,000 immigrants from Bessarabia, registered as "Romanians", but predominantly Russophones, entered the state of São Paulo (RUSEISHVILI, in press). Along the 1930s, another group of stateless Russophones under the Nansen International Office for Refugees protection was resettled from prewar Europe to Brazil.

Any numerical estimate is hard to obtain, but the Brazilian population census data provide some information. The National Census of 1920 registered 32,299 Polish immigrants and 28,941 immigrants from Russia, these numbers corresponded to $2.1 \%$ and $1.8 \%$ of the total amount of foreigners in Brazil, respectively (IBGE, 1927). In 1940, there were 47,039 Polish immigrants in Brazil (3.4\% of total), 27,001 Russians (2.2\%), 15,387 Lithuanians (1.3\%), 13,725 Romanians (1.2\%), and 12,841 Hungarians (1.1\%), among others (IBGE, 1950).

The third period of Russian-speaking immigration began after the end of the Second World War. In virtue of the low accuracy regarding migrant registration by Brazilian 
authorities, the exact number of Russophones who entered Brazil over that period is not known. Between 1947 and 1949, the state of São Paulo registered the arrival of 760 Russians, 808 stateless people, 2,963 Polish and 1,080 Ukrainians (RUSEISHVILI, 2018). Furthermore, in the 1950s, Brazil, by rough estimates, accepted up to nine thousand Russophone refugees from China. They had resided in China since the implantation of the Soviet State, but the advance of the Chinese communism forced them to ask for asylum to the other countries. By the reason of the quotas already set by the US government on that moment, the main destinations for these immigrants were the countries of South America and Australia (RUSEISHVILI, 2018).

In Brazil, the Russophone immigrants from China settled in big urban centers, mainly in São Paulo and Rio de Janeiro. They were younger than Russophone people displaced from Europe: among the heads of the families, $45 \%$ were between 30 and 39 years old (RUSEISHVILI, 2018). Likewise, there was a great number of children: $44 \%$ of total number of Russophones arrived from China were infants and young people less than 29 years old. In the context of a large amount of the single-parent families headed by women, the matter of the childcare was extremely serious. To help them, the oriental order catholic authorities founded two Russian boarding schools: in 1954, São Vladimir Institute (school for boys) in Itu, the hinterland of the state of São Paulo (transferred to Santos in 1958); and in 1958, Santa Olga Institute (school for girls) in Resende, the hinterland of Rio de Janeiro state (HIGA, 2015; VOROBIEFF, 2006). In the 1960s, both institutes moved to the Ipiranga district in São Paulo city. Both schools taught theology, Russian culture and language. All other classes were attended in Brazilian schools. In this way, the children were living in the bilingual environment, having daily contact both with the Portuguese and Russian languages. In the 1970s, when the children of this generation had grown, both schools were closed. By rough estimate based on the IBGE 1950 census (IBGE, 1956), one thousand and half these immigrants could be still alive.

Nowadays, the Chinese Russophone emigrants, their children, and descendants from previous Russophone immigrant waves that live in Brazil and preserve their Russian speech present a great interest for heritage language research. Their next generations rarely maintain proficiency in Russian, and this Brazilian variety of the heritage Russian can be considered moribund.

\subsection{RUSSOPHONE IMMIGRATION IN BRAZIL IN THE $211^{\text {ST }}$ CENTURY}

The fourth period of the Russophone immigration began with the dissolution of the Soviet Union. The collapse of the Soviet Union in 1991 induced a new wave of emigration both from Russia and other former Soviet Republics (ALESHKOVSKI; GREBENYUK; VOROBYEVA, 2018). According to the Rosstat (Russian Federal State Statistics Service) data, approximately 4.3 million people left the Russian Federation during 1993-2016, most 
of them in the early 1990s (VOROBYEVA; ALESHKOVSKI; GREBENYUK, 2018). In the following years, the number of emigrants gradually decreased until 2009; since 2010, the number of emigrants has been once again steadily increasing. These numbers could be underestimated 3-4-fold due to the gaps in the migration registration system (VOROBYEVA; ALESHKOVSKI; GREBENYUK, 2018). The International Organization for Migration (IOM) World Migration Report (2018, p. 19, p. 68) shows that the Russian Federation had the third largest population of its citizens living abroad in the world after India and Mexico, at over 10 million emigrants in 2015. Among the reasons for the emigration are poor prospects for the improvements of material welfare, social status, personal stability, and economic security (VOROBYEVA; ALESHKOVSKI; GREBENYUK, 2018). The Russian citizens search for employment in foreign scientific centers and universities, turn into entrepreneurs, use hosting programs for ethnic migrants, and even apply for asylum. In addition, marriages in host countries have become an important emigration reason since 2001.

In the last 20 years, 7031 Russian citizens were registered by the Brazilian Federal Police in the national register of foreigners authorized to reside in Brazil, as well as 4261 Ukrainians, 548 Kazakhstani and 265 Belarusians (SISMIGRA, Banco Interativo, 2020; SMIRNOVA HENRIQUES; RUSEISHVILI, 2020). Russophones from the former Soviet Republics, not registered as Russians, also represent an important part of the Russianspeaking community. The annual report on the inclusion of immigrants in the Brazilian labor market shows Russians among 15 nationalities who get the greatest number of work permits (QUINTINO; TONHATI, 2017). To study the late bilingualism of such first-generation immigrants, we have recently created a database that contains audio and video recordings of speech samples in Russian and Portuguese produced by 40 speakers of Russian as L1 who reside in São Paulo (SMIRNOVA HENRIQUES et al., 2020).

Many of the Russophone immigrants marry Brazilians and give rise to a next immigration generation who are heritage speakers. The major cities of Brazil, São Paulo, and Rio de Janeiro, have Russian Saturday schools/kindergartens for bilingual children. "Clube Eslavo" (São Paulo) and "Escolinha Russa" (Rio de Janeiro) reported that they had up to 20 children in the best moments of their projects. In São Paulo, the most numerous age group in 2019 was 4-5-year-old children; in Rio de Janeiro, in 2018, 1-4 year-old.

\subsection{BILINGUALISM AND LANGUAGE DOMINANCE}

Language dominance is a central theme in bilingual studies, and it can be easily conflated with language proficiency (BIRDSONG, 2006). However, proficiency in terms of bilingual language skills, such as grammar usage or vocabulary size, is often considered in relation to monolingual language use expectations (BEDORE et al., 2012), while dominance derives from a bilingual nature, coexistence of two languages in one 
mind (GROSJEAN, 1998). Language dominance is multidimensional in nature, and proficiency is only one of its components (BIRDSONG, 2006; BEDORE et al., 2012). There is no common way to determine language dominance in bilinguals. Self-report instruments which rely on subjective information are predominant in this area. Some examples include the Language Experience and Proficiency Questionnaire (LEAP-Q) (MARIAN; BLUMENFELD; KAUSHANSKAYA, 2007), the Bilingual Dominance Scale (BDS) (DUNN; FOX TREE, 2009), and the Bilingual Language Profile (BLP) (BIRDSONG; GERTKEN; AMENGUAL, 2021). There are also objective tests, for example, measures of lexical richness through standardized diversity scores (TREFFERS-DALLER, 2011) or a combination of sentence repetition tasks, translation tasks, and evaluation of foreign accent degree (FLEGE; MACKAY; PISKE, 2002).

As a theoretical background for different strategies for lexical measures, Faria (1996) described the interdependence relations between language and cognition that co-exist in the form of verbal language, perception, attention, and memory. These interdependences become evident in tip-of-tongue states, lexical access difficulties, interference of L2 lexical items in L1 language production, lack of awareness about meaning differences, and in cases when one lexical item activates other semantic domains.

The evaluation of language dominance through foreign accent ratings is based on results of phonetic experimental research that point out bilinguals develop links across the languages they speak (PISKE; MACKAY; FLEGE, 2001). This is the case of crosslanguage assimilations of $\mathrm{L} 2$ sounds to $\mathrm{L} 1$ sounds and the fact that "bilinguals strive to maintain contrast between L1 and L2 phonetic categories, which exist in a common phonological space" (FLEGE, 1995, p. 239). Simonet (2019), analyzing the phonetic behavior of proficient Catalan-Spanish bilinguals, found that non-dominance in one of the languages induced the lack of sound categorization, and results in more processing time and longer speech acoustic inputs to categorize the speech sound contrasts.

The evaluation of language dominance in heritage speakers should consider that this type of bilinguals uses the two languages in different situations, for different purposes and with a different intensity across the lifespan (MONTRUL, 2015). This results in varied fluency and proficiency levels in distinct language skills (listening, speaking, reading, and writing). The speech productions of heritage speakers differ not only based on their linguistic input in the first years of life but also on the patterns of language usage as adults.

\subsection{VERBAL WORKING MEMORY IN BILINGUALS}

All speaking processes - from intention to internal speech production - perform as part of the mental processes ruled by the working memory (FORTKAMP, 1999), which is responsible for the temporary maintenance and ongoing manipulation of verbal 
information (BADDELEY, 1986). The working memory is a part of the domain-general executive function network (BIALYSTOK, 2009; CONWAY et al., 2005). The relations between the verbal working memory and language acquisition, comprehension, and production have been extensively studied (ACHESON; MACDONALD, 2009; FORTKAMP, 1999; MASCARELLO, 2012; WEISSHEIMER; MOTA, 2009).

The majority of the publications devoted to the assessment of the working memory in bilinguals compare monolinguals and bilingual groups (BIALYSTOK, 2009; LEHTONEN et al., 2018; LUKASIK et al., 2018). Some studies also compared the working memory capacity between two languages of a bilingual (ARDILA et al., 2000; GUTIÉRREZ-CLELLEN; CALDERÓN; WEISMER, 2004; HUMMEL, 2002; OSAKA; OSAKA, 1992; OSAKA; OSAKA; GRONER, 1993; XUE et al., 2004). Many theoreticians claim that bilinguals have one conceptual and two separate lexical stores for each language (BOT et al., 1995; GROSJEAN, 1982; PARADIS, 1985; POULISSE, 1993). Thus, the working memory capacity in the two languages of a bilingual can vary. The performance can be affected by the nature of the task, speaker's language preference and proficiency (GUTIÉRREZ-CLELLEN; CALDERÓN; WEISMER, 2004).

Xue et al. (2004) showed that unbalanced Chinese-English bilinguals with lower proficiency in L2 performed better in semantic and phonological tasks in their L1. Ardila et al. (2000) found that early Spanish-English bilinguals, highly proficient in both languages, also performed better in the verbal memory subtests in L1. Grundy and Timmer (2017) concluded, through a meta-analysis, that bilinguals perform the working memory tasks better in their dominant language. Vejnović, Milin and Zdravković (2010) showed that the working memory in L2 of Serbian-English bilinguals, evaluated through a complex-span task, depends on the proficiency level and age of acquisition; performance in the L2 is not affected by these factors. However, in other studies, the results obtained for the two languages of highly proficient speakers were strongly correlated (JapaneseEnglish bilinguals, OSAKA; OSAKA, 1992; German-French bilinguals, OSAKA; OSAKA; GRONER, 1993; French-English bilinguals, HUMMEL, 2002; Spanish-English bilinguals, GUTIÉRREZ-CLELLEN; CALDERÓN; WEISMER, 2004). Several recent meta-analyses do not find any positive effect of bilingualism on the working memory capacity; these inconsistent results are explained by the publication bias between positive and negative results (LEHTONEN et al., 2018; LUKASIK et al., 2018).

Measures of working memory are important in the experiments with assessment of narratives in bilinguals because the working memory capacity influences performance in the picture description tasks (KORMOS; TREBITS, 2011; TSIMPLI et al., 2014; TSIMPLI; PERISTERI; ANDREOU, 2016). The studies of aphasic and non-aphasic language impairments suggest a relationship between the working memory capacity and discourse 
production aspects, such as macrolinguistic narrative components (CAHANA-AMITAY; JENKINS, 2018; YOUSE; COELHO, 2005).

In Latin America, working memory studies related to language are quite recent but encompass a wide range of questions as language acquisition, metapragmatic awareness, bilingualism, phonological and syntactical aspects (CRESPO ALLENDE; ALVARADO BARRA, 2010; FINARDI; SILVEIRA, 2011; GINDRI; KESKE-SOARES; MOTA, 2007; KRAMER; MOTA, 2015; TESSMAN BANDEIRA, 2008). Topics such as L2 acquisition and production (fluency, accuracy, and complexity), and teaching strategy development, are prioritized (FINARDI, 2008; FONTANINI et al., 2005; GUARÁ-TAVARES, 2013; MATIELO; OLIVEIRA; BARETTA, 2018; MOTA, 2003; PREBIANCA; FINARDI; WEISSHEIMER, 2014; ORTIZ-PREUSS, 2019). Only few studies considered the working memory measurements in the immigrant populations (KRAMER; MOTA, 2015).

There are many ways to measure the working memory capacity which involve different kinds of stimuli (words, numbers, phrases, etc.) and operations executed over them (recalling the elements in established order, producing grammatical phrases, etc.) (JUST; CARPENTER, 1992). The working memory capacity involves the same fundamental processes as language production, that is, the storage and processing of ongoing information. While the storage component is responsible for memorizing the stimuli, the processing component orders them (FORTKAMP, 1999). One of the most reliable and valid measures of the working memory capacity is a span task (CONWAY et al., 2005).

In the present study, we apply the Month-Ordering task because it allows us to avoid the influence of the vocabulary size in unbalanced bilinguals. This task requires using very common vocabulary (names of months) which is well known even by heritage speakers. This task was proposed by Kempler et al. (1998) for English-speaking Alzheimer's disease patients and later extended by Goral et al. (2011) to monolingual elderly English-speaking adults. A recent modification of this task was applied to the Portuguese speakers in Portugal, and the results proved that this method is internally consistent and temporally stable (BUEKENHOUT; LEITÃO; GOMES, 2018). Its scores predict the efficiency of language comprehension processes, and this task is considered suitable even for patients with significant cognitive impairments and/or individuals with very low educational attainment. 


\section{METHODS}

\subsection{PARTICIPANTS}

The sample included 77 participants divided in two groups: the first-generation Russophone immigrants that have lived in Brazil for at least two years, and elderly Russian heritage speakers who have lived in Brazil for the most part of their life or even their whole life. The study was approved by the Ethics Committee of Pontifícia Universidade Católica de São Paulo (CAAE 09079219.9.0000.5482).

The group of the first-generation Russophone immigrants included 49 participants, speakers of Russian as L1, who self-identified as proficient in Portuguese. All of them acquired Portuguese as adults and are considered to be late L1 Russian - L2 Brazilian Portuguese bilinguals. As in many other studies that characterize the speech of different migrant generations (ALBA et al., 2002; BAHRICK et al., 1994; CONNAUGHTON-CREAN; Ó DUIBHIR, 2017; PORTES; HAO, 1998; SEVINÇ, 2016), we consider that first-generation immigrants are dominant in their L1, Russian. Five participants also spoke Ukrainian.

In the group of the first-generation Russophone immigrants, ten participants were men and 39 women. The mean age of the participants was 38.5 years $(S D=8.9$ ), range 24 to 58 years; the mean time of residence in Brazil was 9 years $(S D=5.9)$, range 2 to 30 years. Thirty-nine participants resided in São Paulo, four in other cities of the state of São Paulo, three in Rio de Janeiro, one in Brasilia, one in Curitiba, and one in Salvador. At least 43 participants, $88 \%$ of the sample, had a college degree. The most mentioned occupations were instructors of Russian (14 participants), administrators, economists, or financial specialists (11), university professors of Mathematics or Physics (5), and housewives (4). Twenty participants were selected from our database of 40 Russophone immigrants living in São Paulo (Smirnova Henriques et al., 2020), the others were recruited through personal contact.

The group of elderly heritage Russian speakers consisted of 28 participants older than 58 years who acquired Portuguese as children or young men/women. Since they spent most of their life in Brazil, most of them should be dominant in Portuguese. Later analysis of the Bilingual Language Profile (BIRDSONG; GERTKEN; AMENGUAL, 2021) in this group showed that $80 \%$ of 23 participants that answered the questionnaire were in fact dominant in Portuguese (unpublished). Some of the speakers reported usage of other languages in their everyday life, but only three participants informed that they spoke other languages on a weekly basis. The frequency of their third language usage was selfevaluated by these participants as no more than $20 \%$ of the general speaking time.

In the group of elderly heritage Russian speakers, 11 participants were men and 17 women. The mean age of the participants was 75.8 years $(S D=7.8)$, range 59 to 98 years. In this group, 23 participants resided in São Paulo, two in other cities in the state of São Paulo and three in Rio de Janeiro. Thirteen were born in China; nine, in Brazil; three, in Europe; three, in Russia or Belarus. For 19 participants who were not born in Brazil the 
mean age at arrival was 10.3 years $(S D=5.7)$, range 1 to 24 years. Only one participant arrived in Brazil at the age older than 17 years, she was born in Paris. At least 18 participants, $64 \%$ of the sample, had a college degree. All elderly Russian heritage speakers were from the database of the BraPoRus, a corpus of oral speech samples of Russian heritage-Brazilian Portuguese bilinguals (SMIRNOVA HENRIQUES et al., 2021).

\subsection{VERBAL WORKING MEMORY MEASURE}

For verbal working memory measure, the Month-Ordering task (KEMPLER et al., 1998; GORAL et al., 2011) was translated into Russian and Portuguese. In this task, participants listen to an increasingly long set (from 2 to 7 ) of months, presented out of calendar order, and are asked to recall the months back in the order they appear in the calendar. The sets of months in English are presented in Table 1. At each span level, there were four sequences; testing was stopped when two items at a span level were recalled incorrectly. The number of months in the last block which contained more than two correct sequences was considered the working memory span of participant. The tasks were administered in both languages (Russian and Portuguese) in the order established by assessor, speaker of Russian as L1 and Portuguese as L2. In the group of the first-generation Russophone immigrants, 27 participants first took the test in Russian and 22 in Portuguese. In the group of elderly Russian heritage speakers, 14 participants first took the test in Russian and 14 in Portuguese.

\begin{tabular}{|c|c|}
\hline Span level & Stimuli \\
\hline 2 & $\begin{array}{l}\text { - May, March } \\
\text { - November, September } \\
\text { - April, June } \\
\text { - July, October }\end{array}$ \\
\hline 3 & $\begin{array}{l}\text { - May, February, March } \\
\text { - December, August, April } \\
\text { - March, July, May } \\
\text { - June, November, September }\end{array}$ \\
\hline 4 & $\begin{array}{l}\text { - May, April, January, July } \\
\text { - October, March, September, June } \\
\text { - December, April, September, October } \\
\text { - September, May, February, August }\end{array}$ \\
\hline 5 & $\begin{array}{l}\text { - January, June, March, May, April } \\
\text { - March, August, February, May, November } \\
\text { - June, March, May, April, August } \\
\text { - January, February, August, May, December }\end{array}$ \\
\hline 6 & $\begin{array}{l}\text { - February, August, January, April, September, July } \\
\text { - March, August, October, May, January, April } \\
\text { - September, January, October, August, February, June } \\
\text { - April, September, July, June, August, May }\end{array}$ \\
\hline 7 & $\begin{array}{l}\text { - March, July, April, January, December, August, June } \\
\text { - July, May, November, February, December, October, April } \\
\text { - April, July, June, September, November, March, December } \\
\text { - June, February, May, January, March, October, August }\end{array}$ \\
\hline
\end{tabular}

Table 1. Stimuli used in the Month-Ordering task for working memory measure (KEMPLER et al., 1998; GORAL et al., 2011). In the current test, the task was translated into Russian and Portuguese. 
Due to the sanitary restrictions to prevent the spread of COVID-19, the participants were tested by phone; the call was scheduled by the research assistant prior to testing. At the beginning of the test session, the participant was asked about the quality of the sound to check if it was adequate for conducting the test. Then, the assistant introduced the participant to the task, collected the personal data (age, time, and place of residence in Brazil, profession) and conducted the Month-Ordering task. The beginning of each language block was announced in the language of the task. The answers were compared with the correct answers from the protocol and recorded immediately in the spreadsheet. Each test lasted around 7-15 min.

\subsection{STATISTICAL PROCEDURES}

The median, mean values and standard deviations $(S D)$ for the scores were calculated in Excel. The normality of the distributions was verified through the Kolmogorov-Smirnov (KS) Test of Normality, available online (STANGROOM, 2021). The correlations were verified through the Spearman's Rho correlation calculator (STANGROOM, 2021). The comparisons between two languages of the same sample, containing paired data, were performed using Wilcoxon signed-ranks test; the comparisons between two samples were performed using Mann-Whitney test (STANGROOM, 2021).

\section{RESULTS}

In this section, we describe the assessment of the working memory capacity through the Month-Ordering task in the first-generation immigrants, late Russian-Portuguese bilinguals, and elderly Russian heritage speakers who speak Portuguese as the societal language for most part of their life.

In the group of the 49 late Russian-Portuguese bilinguals, the median Month-Ordering spans for Russian and Portuguese were 5 and 4, respectively (Table 2).

\begin{tabular}{lcccc} 
& \multicolumn{2}{c}{ Month-Ordering span } \\
\hline & Russian-Portuguese late bilinguals & \multicolumn{1}{c}{ Elderly Russian heritage-Portuguese bilinguals } \\
\hline Russian & Portuguese & Russian & Portuguese \\
\hline Mean & 4.5 & 4.4 & 3.9 & 4.8 \\
\hline Median & 1.2 & 1 & 1.5 & 1.5 \\
\hline
\end{tabular}

Table 2. Working memory capacity (Month-Ordering span) in Russian and Portuguese languages in 49 late Russian-Portuguese bilinguals and 28 elderly Russian heritage-Portuguese bilinguals as measured through Month-Ordering task. 
For the late Russian-Portuguese bilinguals, the distributions of Month-Ordering spans for both languages were not normal (Figure 1A). There was no statistical difference in the working memory scores between the languages. Sixteen participants showed numerically higher working memory scores in Russian, 12 in Portuguese and 21 had the same scores in both languages.

\section{A}

\section{B}

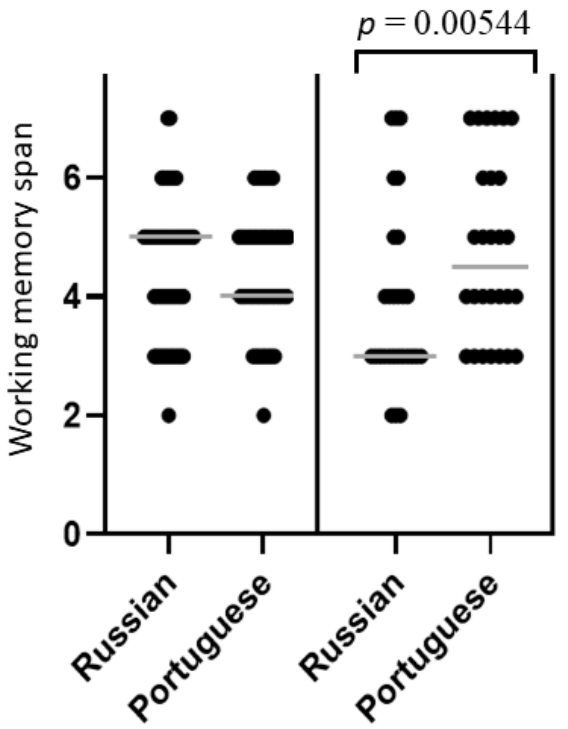

Figure 1. Working memory capacity (Month-Ordering span) in Russian and Portuguese languages in 49 late Russian-Portuguese bilinguals (A) and 28 elderly Russian heritage-Portuguese bilinguals (B) as measured through Month-Ordering task. Grey horizontal lines show the median values for each language in each group.

For the late Russian-Portuguese bilinguals, the Month-Ordering spans obtained in Russian and in Portuguese were correlated (Table 3). There were no correlations between the working memory capacity and the age of the participants, time of their residence in Brazil, or order of the language presentation in the task (Table 3).

Spearman's correlation coefficient

\begin{tabular}{|c|c|c|}
\hline & Month-Ordering span, Russian & Month-Ordering span, Portuguese \\
\hline$\overline{\mathrm{Age}}$ & $\begin{array}{l}r=-0.0187 \\
p=0.89852\end{array}$ & $\begin{array}{l}r=-0.01706 \\
p=0.90736\end{array}$ \\
\hline $\begin{array}{l}\text { Time of residence in } \\
\text { Brazil }\end{array}$ & $\begin{array}{l}r=0.13336 \\
p=0.36097\end{array}$ & $\begin{aligned} r & =0.2418 \\
p & =0.09416\end{aligned}$ \\
\hline $\begin{array}{l}\text { Order of language } \\
\text { presentation in the } \\
\text { task }\end{array}$ & $\begin{array}{l}r=0.01206 \\
p=0.93446\end{array}$ & $\begin{array}{l}r=0.01364 \\
p=0.9259\end{array}$ \\
\hline $\begin{array}{l}\text { Correlation between } \\
\text { the working memory } \\
\text { spans in Russian and }\end{array}$ & & \\
\hline
\end{tabular}

Portuguese

Table 3. Verification of the variables related to the working memory capacity in Russian and Portuguese for 49 late Russian-Portuguese bilinguals. 
In the group of 28 elderly Russian heritage-Portuguese bilinguals, the median MonthOrdering spans for Russian and Portuguese were 3 and 4.5, respectively (Table 2, Figure 1B). The distribution of the scores was normal in Portuguese, but not in Russian. The median working memory score in Russian was 1.5-fold lower than in Portuguese (Wilcoxon signed-ranks test, $p=0.00544$ ). Four participants showed numerically higher working memory scores in Russian, 15 in Portuguese and 9 had the same scores in both languages. The Month-Ordering spans obtained in Russian and in Portuguese were correlated (Table 4). There were no correlations between the working memory capacity and the age of participants or order of the language presentation in the task (Table 4).

Spearman's correlation coefficient

\begin{tabular}{|c|c|c|}
\hline & Month-Ordering span, Russian & Month-Ordering span, Portuguese \\
\hline$\overline{\mathrm{Age}}$ & $\begin{array}{l}r=-0.34034 \\
p=0.07638\end{array}$ & $\begin{array}{l}r=-0.04145 \\
p=0.83413\end{array}$ \\
\hline $\begin{array}{l}\text { Order of language } \\
\text { presentation in the } \\
\text { task }\end{array}$ & $\begin{array}{l}r=0.06491 \\
p=0.7428\end{array}$ & $\begin{array}{l}r=0 \\
p=1\end{array}$ \\
\hline $\begin{array}{l}\text { Correlation between } \\
\text { the working memory }\end{array}$ & & \\
\hline
\end{tabular}

spans in Russian and

Portuguese

Table 4. Verification of the variables related to the working memory capacity for 28 elderly Russian heritagePortuguese bilinguals.

In the comparison between the groups of 49 late Russian-Portuguese bilinguals and 28 elderly Russian heritage-Portuguese bilinguals, the Month-Ordering spans in Portuguese were not different, but in Russian, the elderly Russian heritage-Portuguese bilinguals had 1.7-fold lower scores than the not-elderly late Russian-Portuguese bilinguals (Mann-Whitney test, $z$-score $=2.1708, p=0.03$ ).

\section{DISCUSSION AND FUTURE DIRECTIONS}

In the current work, we assessed the working memory capacity, in Russian and in Portuguese, in two groups of participants: (i) the first-generation immigrants who acquired Russian as children in Russian-speaking homeland and Portuguese as adults, predicted to be dominant in Russian, and (ii) the Russian heritage speakers who acquired Russian as children but have spent most of their time in Brazil, speak Portuguese as the societal language and, in most cases, consider themselves to be dominant in Portuguese. While the working memory scores of the first-generation Russophone immigrants were not different between the languages, the median score of the elderly Russian heritage speakers in Russian was 1.5-fold lower than in Portuguese (Figure 1). In the comparison between the two groups, their working memory capacity measured in Portuguese was the 
same, while in Russian the elderly Russian heritage-Portuguese bilinguals got 1.7-fold lower scores than the first-generation immigrants. In both groups, no correlations were found between the working memory capacity and the age of participants or the language presentation order in the task. The time of residence in Brazil of the first-generation Russophone immigrants also did not affect the scores.

In previous studies, the Month-Ordering task was used only with monolinguals (BUEKENHOUT; LEITÃO; GOMES, 2018; GORAL et al., 2011; KEMPLER et al., 1998); in the monolingual conditions, it was established that its scores predict the efficiency of language comprehension processes (BUEKENHOUT; LEITÃO; GOMES, 2018). However, even though the performance of unbalanced bilinguals in the Month-Ordering task should not be influenced by the vocabulary size, it can be influenced by the vocabulary processing speed. We hypothesize that the fact that the first-generation immigrants have the same working memory capacity in both languages can be explained by the regular use of both languages in everyday life. The Russian heritage speakers, even though they know the month names well, rarely use them in Russian, and this could affect the processing of this vocabulary category.

In the studies of Kramer and Mota (2015), younger bilingual Brazilian PortugueseHunsrückisch speakers showed better working memory scores in Portuguese than elderly bilinguals in the measurement of Alpha span task. We have seen this effect only for the less used language (Russian) of the Russian heritage speakers, but not for Portuguese, even considering that the groups of the first generation Russophone immigrants and Russian heritage speakers had a big difference in terms of age (mean ages of 38.5 and 75.8 years, respectively). However, the results obtained by Kramer and Mota (2015) could be influenced by the different education levels in their samples: the elderly Brazilian population has a lower education level, and it is difficult to match the samples by this criterion. In their experiments, the elderly bilinguals had only 5.3 years of formal education. The mismatch in socioeconomic status and education is well known as an important factor that biases the working memory measurements (LEHTONEN et al., 2018; LUKASIK et al., 2018). In our experiments, the elderly Russophone immigrants that have grown in Brazil had more opportunities, and at least $64 \%$ of them had a college degree.

One factor that we did not consider in this study is a potential influence of third languages spoken by participants. In fact, some first-generation Russophone immigrants also spoke Ukrainian, and a few Russian heritage speakers reported some weekly use of their third languages. Probably, many of the participants studied English or other languages at school or university. However, in the 21st century, the time of globalization, travels, internet, and an easy access to learning, it is very difficult to find real "monolinguals" or "bilinguals" or describe in a comprehensive way a multilingual profile of the speakers. In the current study, we use the term "bilinguals" to emphasize that the 
research is focused on Russian and Brazilian Portuguese that are the main languages used by the participants in their everyday life.

In fact, 23 out of the 28 Russian heritage speakers filled out the self-evaluation questionnaire of the Bilingual Language Profile protocol during the data collection for the BraPoRus corpus, and their language dominance profiles have been defined: 18 were dominant in Portuguese, one was balanced bilingual, and four were dominant in Russian (unpublished). However, the first-generation immigrants did not perform this task yet, thus, these data can not be compared, and the relation between the self-evaluated language dominance and working memory will be evaluated in a next step.

The data on the working memory capacity in Russian and Portuguese of the elderly Russian heritage-Brazilian Portuguese bilinguals are meant to provide a base to verify the relation between the working memory capacity and narrative production abilities of the heritage speakers in their heritage and societal languages. The narrative abilities of bilinguals will be assessed using the MAIN protocol (GAGARINA et al., 2016) that already exists in Russian and Brazilian Portuguese versions. To the best of our knowledge, until now, the Russian heritage-Brazilian Portuguese early bilinguals from old immigration waves to Brazil have been studied only in the sociological and historical aspects (RUSEISHVILI, 2016; VOROBIEFF, 2006), and their linguistic profile remains unknown.

Considering that the main reason of the present study was to provide a basis for the future analysis of narrative abilities, we have not performed any comparison of the working memory scores with monolinguals. However, we plan to make these comparisons in our future work, carefully matching the samples by education level. The age-related losses in the executive function are expected to be attenuated by bilingualism (BIALYSTOK et al., 2004; BIALYSTOK; CRAIK; FREEDMAN, 2007), but this has never been verified using the Month-Ordering task.

\section{ACKNOWLEDGMENTS}

Dr. Smirnova Henriques is supported by postdoctoral fellowship PNPD/CAPES (Programa Nacional de Pós-Doutorado da Coordenação de Aperfeiçoamento de Pessoal de Nível Superior). We thank all our participants for the kind agreement to take part in our research. We also thank Snizhana Maznova, director of "Clube Eslavo" (São Paulo), and Ksenia Zortea, director of "Escolinha Russa" (Rio de Janeiro), for their interviews about the bilingual education of the Russophone children in Brazil. 


\section{REFERENCES}

ABREU MORATO, Geanne Alves de. Situando a língua japonesa no contexto da história do ensino de línguas no Brasil. HELB, n. 5, 2011. Available at: http://www.helb.org.br/index.php/revista-helb/ano-5-no-5-12011/190situando-a-lingua-japonesa-no-contexto-da-historia-do-ensino-de-linguas-no-brasil. Accessed on: 13 August 2021.

ACHESON, Daniel J.; MACDONALD, Maryellen C. Verbal working memory and language production: common approaches to the serial ordering of verbal information. Psychological Bulletin, v. 135, n. 1, p. 50-68, 2009. DOI https://doi.org/10.1037/a0014411

ALBA, Richard; LOGAN, John; LUTZ, Amy; STULTS, Brian. Only English by the third generation? Loss and preservation of the mother tongue among the grandchildren of contemporary immigrants. Demography, v. 39, p. 467-484, 2002. DOI https://doi.org/10.1353/dem.2002.0023

ALESHKOVSKI, Ivan A.; GREBENYUK, Alexander; VOROBYEVA, Olga. The Evolution of Russian Emigration in the PostSoviet Period. Social Evolution and History, v. 17, n. 2, p. 140-155, 2018. DOI https://doi.org//10.30884/seh/2018.02.09

D’ALESSANDRO, Roberta; NATVIG, David; PUTNAM, Michael T. Addressing Challenges in Formal Research on Moribund Heritage Languages: A Path Forward. Frontiers in Psychology, v. 12, 2021. DOI https://doi.org/10.3389/fpsyg.2021.700126

ALTENHOFEN, Cleo Vilson; MORELLO, Rosângela (Org.) Hunsrückisch: inventário de uma língua do Brasil. Florianópolis: Garapuvu, 2018. Available at: https://lume.ufrgs.br/handle/10183/194384. Accessed on: 13 August 2021.

ARDILA, Alfredo; ROSSELLI, Mónica; OSTROSKY-SOLIS, Feggy; MARCOS, José; GRANDA, Gladys; SOTO, Miguel. Syntactic comprehension, verbal memory, and calculation abilities in Spanish-English bilinguals. Applied Neuropsychology, v. 7, n. 1, p. 3-16, 2000. DOI https://doi.org/10.1207/s15324826an0701_2

AU, Terry Kit-fong; OH, Janet S.; KNIGHTLY, Leah. M.; JUN, Sun-Ah; ROMO, Laura F. Salvaging a Childhood Language. Journal of Memory and Language, v. 58, n. 4, p. 998-1011, 2008. DOI https://doi.org/10.1016/i.jml.2007.11.001

AU, Terry Kit-fong; ROMO, Laura F. Does childhood language experience help adult learners? In: CHEN, Hsuan-chih (Ed.). The Cognitive Processing of Chinese and related Asian Languages. Hong Kong: The Chinese University of Hong Kong Press, 1997, p. 417-441.

BADDELEY, Alan. Working memory. Oxford: Oxford University Press, 1986.

BAHRICK Harry: HALL, Lynda K· BAHRICK, Lorraine; GOGGIN Judith P. BERGER, Stephanie A. Fifty Years of Language Maintenance and Language Dominance in Bilingual Hispanic Immigrants. Journal of Experimental Psychology General, v. 123, n. 3, p. 264-283, 1994. DOI https://doi.org/10.1037/0096-3445.123.3.264

BEDORE, Lisa M.: PEÑA, Elizabeth D.; SUMMERS, Connie L.; BOERGER, Karin M.: RESENDIZ, Maria D.; GREENE, Kai; BOHMAN, Thomas M.; GILLAM, Ronald B. The measure matters: Language dominance profiles across measures in Spanish-English bilingual children. Bilingualism: Language and Cognition, v. 15, n. 3, p. 616-629, 2012. DOI https://doi.org/10.1017/S1366728912000090

BENINCÁ, Ludimilla Rupf. Sócio-história do contato entre o vêneto e o português: um estudo de caso. PAPIA: Revista Brasileira de Estudos do Contato Linguístico, v. 28, n. 1, p. 109-132, 2018. Available at: http://revistas.fflch.usp.br/papia/article/view/3029. Accessed on: 13 August 2021

BIALYSTOK, Ellen. Bilingualism: The good, the bad, and the indifferent. Bilingualism: Language and Cognition, v. 12, n. 1, p. 3-11, 2009. DOI https://doi.org/10.1017/S1366728908003477

BIALYSTOK, Ellen; CRAIK, Fergus I. M.; FREEDMAN, Morris. Bilingualism as a protection against the onset of symptoms of dementia. Neuropsychologia, v. 45, n. 2, p. 459-464, 2007. DOI https://doi.org/10.1016/i.neuropsychologia.2006.10.009

BIALYSTOK, Ellen; CRAIK, Fergus I. M; KLEIN, Raymond; VISWANATHAN, Mythili. Bilingualism, aging and cognitive control: Evidence from Simon task. Psychology and aging, v. 19, n. 2, p. 290-303, 2004. DOI https://doi.org/10.1037/0882-7974.19.2.290

BIRDSONG, David. Dominance, proficiency, and second language grammatical processing. Applied Psycholinguistics, v. 27, n. 1, p. 46-49, 2006. DOI https://doi.org/10.1017/S0142716406060048 
BIRDSONG, David; GERTKEN, Libby M.; AMENGUAL, Mark. Bilingual language profile: an easy-to-use instrument to assess bilingualism. Available at: https://sites.la.utexas.edu/bilingual/. Accessed on: 17 September 2021.

BLAY, Eva Alterman. O Brasil como destino. Raízes da imigração judaica contemporânea para São Paulo. São Paulo: Editora UNESP, 2013

BOLGER, Patrick A.; ZAPATA, Gabriela C. Psycholinguistic Approaches to Language Processing in Heritage Speakers. Heritage Language Journal, v. 8, n. 1, p.1-29, 2011. Available at: https://brill.com/downloadpdf/journals/hli/8/1/articlep1_2.pdf. Accessed on: 18 September 2021.

BORSTEL, Clarice Nadir Von. Aspectos do bilinguismo: alemão/portugues em Marechal Candido Rondon-ParanaBrasil. 185 p. Dissertation (Master's degree in Language Studies) - Centro de Comunicação e Expressão, Universidade Federal de Santa Catarina, Florianópolis, 1992. Available at:

http://repositorio.ufsc.br/xmlui/handle/123456789/76864. Accessed on: 13 August 2021.

BOT, Kees de; COX, Albert; RALSTON, Steven; SCHAUFELI, Anneli; WELTENS, Bert. Lexical processing in bilinguals. Second language research, n. 11, p. 1-19, 1995. DOI https://doi.org/10.1177/026765839501100101

BUEKENHOUT, Imke; LEITÃO, José; GOMES, Ana A. A New Test for the Assessment of Working Memory in Clinical Settings: Validation and Norming of a Month Ordering Task. Psychological Assessment, v. 30, n. 10, p. 1367-1381, 2018 DOI https://doi.org/10.1037/pas0000585

BYTSENKO Anastassia Imigração da Rússia para o Brasil no início do século XX. Visões do paraíso e do inferno 134 p. Dissertation (Master's degree in Language Studies) - Faculdade de Filosofia, Letras e Ciências Humanas, Universidade de São Paulo, São Paulo, 2006. Available at: https://www.teses.usp.br/teses/disponiveis/8/8155/tde12112007-132926/pt-br.php. Accessed on: 13 August 2021.

CAHANA-AMITAY, Dalia; JENKINS, Theodore. Working memory and discourse production in people with aphasia. Journal of Neurolinguistics, n. 48, p. 90-103, 2018. DOI https://doi.org/10.1016/i.jneuroling.2018.04.007

COMIOTTO, Ariela Fátima; MOTA, Mailce Borges; SOARES, Eduardo Correa. O code-switching em bilíngues talianportuguês sob uma abordagem psicolinguística. Linguagem \& Ensino, v. 23, n. 4, p. 1121-1144, 2020. DOI https://doi.org/10.15210/RLE.V2314.18570

CONNAUGHTON-CREAN, Lorraine; Ó DUIBHIR, Pádraig. Home language maintenance and development among first generation migrant children in an Irish primary school: An investigation of attitudes. Journal of Home Language Research, v.2, p. 22-39, 2017. DOI https://doi.org/10.16993/ihlr.29

CONWAY, Andrew R. A.; KANE, Michael J.; BUNTING, Michael F.; HAMBRICK, Zach D.; WILHELM, Oliver; ENGLE, Randall W. Working memory span tasks: A methodological review and user's guide. Psychonomic Bulletin \& Review, V. 12, n. 5, p. 769-786, 2005. DOI https://doi.org/10.3758/BF03196772

COSTA, Luciane Trennephol da: LOREGIAN-PENKAL, Loremi. A coleta de dados do banco VARLINFE - Variação Linguística de Fala Eslava: peculiariedades e características. Revista Conexão da UEPG, v. 11, n. 1, p. 102-111, 2015 Available at: https://www.revistas2.uepg.br/index.php/conexao/article/view/6874. Accessed on: 13 August 2021

CRESPO ALLENDE, Nina: ALVARADO BARRA, Carola. Conciencia metapragmática y memoria operativa en niños escolares. Literatura y Lingüistica, n. 21, p. 93-108, 2010. DOI http://dx.doi.org/10.4067/S0716-58112010000100008

CUMMINS, Jim. A proposal for action: Strategies for recognizing heritage language competence as a learning resource within the mainstream classroom. The Modern Language Journal, v. 89, n. 4, p. 585-592, 2005

DUNN, Alexandra L.; FOX TREE, Jean E. A quick, gradient Bilingual Dominance Scale. Bilingualism: Language and Cognition, v. 12, n. 3, p. 273-289, 2009. DOI https://doi.org/10.1017/S1366728909990113

FAGGION, Carmen Maria; LUCHESE, Terciane Ângela. Producing Silencing: Portuguese Teaching/Learning in Rura Schools in the Italian Colonial Region, Brazil. American Journal of Educational Research, v. 4, n. 5, p. 412-419, 2016.

FARIA, Isabel Hub. Linguagem Verbal: aspectos biológicos e cognitivos. In: FARIA, Isabel Hub; PEDRO, Emília Ribeiro; DUARTE, Inês; GOUVEIA, Carlos A. M. (Orgs.). Introdução à Linguística Geral e Portuguesa. Colecção Universitária, série Linguística dirigida por Maria Raquel Delgado-Martins. 1. ed. Lisboa: Editorial Caminho, 1996. p. 35-56.

FINARDI, Kyria. Working memory capacity and L2 speech production in a picture description task with repetition Revista de estudos da linguagem, v. 16, n. 2, p. 129-144, 2008. DOI https://doi.org/10.17851/2237-2083.16.2.129-144 
FINARDI, Kyria R.; SILVEIRA, Rosane. Working memory capacity in the production and acquisition of a syntactic rule in L2 speech. Revista Brasileira de Linguística Aplicada, v. 11, n. 1, p. 199-221, 2011. DOI https://doi.org/10.1590/S198463982011000100011

FLEGE, James Emil. Second-language Speech Learning: Theory, Findings, and Problems. In: STRANGE, Winifred (Ed.). Speech Perception and Linguistic Experience: Issues in Cross-language Research. Timonium: York Press, 1995. p. 229-273.

FLEGE, James Emil; MACKAY, Ian R. A.; PISKE, Thorsten. Assessing bilingual dominance. Applied psycholinguistics, v. 23, p. 567-598, 2002. DOI https://doi.org/10.1017.S0142716402004046

FINARDI, Kyria. Working memory capacity and L2 speech production in a picture description task with repetition Revista de estudos da linguagem, v. 16, n. 2, p. 129-144, 2008. DOI https://doi.org/10.17851/2237-2083.16.2.129-144

FINARDI, Kyria R.; SILVEIRA, Rosane. Working memory capacity in the production and acquisition of a syntactic rule in L2 speech. Revista Brasileira de Linguística Aplicada, v. 11, n. 1, p. 199-221, 2011. DOI https://doi.org/10.1590/S198463982011000100011

FONTANINI, Ingrid; WEISSHEIMER, Janaina; BERGSLEITHNER, Joara Martin; PERUCCI, Magareth; D’ELY, Raquel. Memória de trabalho e desempenho em tarefas de L2. Revista brasileira de linguística aplicada, v. 5, n. 2, p. 189-230, 2005. DOI https://doi.org/10.1590/S1984-63982005000200009

FORTKAMP, Mailce Borges Mota. Working memory capacity and aspects of $L 2$ speech production. Communication \& Cognition, v. 32, n. 3/4, p. 259-295, 1999.

GAGARINA, Natalia; KLOP, Daleen; TSIMPLI, lanthi M.; WALTERS, Joel. Narrative abilities in bilingual children. Applied Psycholinguistics, v. 37, n. 1, p. 11-17, 2016. DOI https://doi.org/10.1017/S0142716415000399

GERTKEN, Libby M.; AMENGUAL, Mark; BIRDSONG, David. Assessing language dominance with the Bilingual Language Profile. In: LECLERCQ, Pascale; EDMONDS, Amanda; Hilton, Heather (Eds.). Measuring L2 Proficiency: Perspectives from SLA. Bristol: Multilingual Matters, 2014. p. 208-225. DOI https://doi.org/10.21832/9781783092291014

GEWEHR-BORELLA, Sabrina; ZIMMER, Márcia Cristina; ALVES, Ubiratã Kickhöfel. Transferências grafo-fônicofonológicas: uma análise de dados de crianças monolíngues (Português) e bilíngues (Hunsrückisch-Português) Gragoatá, v. 16, n. 30, p. 201-219, 2011. DOI https://doi.org/10.22409/gragoata.v16i30.32931

GINDRI, Gigiane; KESKE-SOARES, Márcia; MOTA, Helena Bolli. Memória de trabalho, consciência fonológica e hipótese de escrita. Pró-Fono Revista de Atualização Científica, v. 19, n. 3, p. 313-322, 2007. DOI https://doi.org/10.1590/S0104-56872007000300010

GORAL, Mira; CLARK-COTTON, Manuella; SPIRO, Avron III; OBLER, Loraine K.; VERKUILEN, Jay; ALBERT, Martin L. The Contribution of Set Switching and Working Memory to Sentence Processing in Older Adults. Experimental Aging Research, v. 37, n. 5, p. 516-538, 2011. DOI https://doi.org/10.1080/0361073X.2011.619858

GROSJEAN, François. Life with two languages. Cambridge: Harvard University Press, 1982.

GROSJEAN, Francois. Studying bilinguals: Methodological and conceptual issues. Bilingualism: Language and Cognition, v. 1, n. 2, p. 131-149, 1998. DOI https://doi.org/10.1017/S136672899800025X

GROSJEAN, François; LI, Ping. The psycholinguistics of bilingualism. New Jersey: Wiley-Blackwell, 2013.

GRUNDY, John G.; TIMMER, Kalinka. Bilingualism and working memory capacity: A comprehensive metaanalysis. Second Language Research, v. 33, n. 3, p. 325-340, 2017. DOI https://doi.org/10.1177/0267658316678286

GUARÁ-TAVARES, Maria da Glória. Working memory capacity and L2 speech performance in planned and spontaneous conditions: a correlation analysis. Trabalhos em linguística aplicada, v. 52. n. 1, p. 9-29, 2013. DOI https://doi.org/10.1590/S0103-18132013000100002

GUTIÉRREZ-CLELLEN, Vera F.; CALDERÓN, Janet; WEISMER, Susan Ellis. Verbal working memory in bilingual children. Journal of Speech, Language, and Hearing Research, v. 47, n. 4, p. 863-876, 2004. DOI https://doi.org/10.1044/1092-4388(2004/064)

HIGA, Bárbara Silva. O instituto São Vladimir e a presença russa em Santos, pela voz dos imigrantes (1958 - 1968). Term paper (Major in History) - Universidade Católica de Santos, Santos, 2015. 
HUMMEL, Kirsten M. Second language acquisition and verbal working memory. In: FABBRO, Franco. (Ed.). Advances in the neurolinguistics of bilingualism: Essays in honor of Michel Paradis. Udine: Forum, 2002. p. 95-118.

IBGE - INSTITUTO BRASILEIRO DE GEOGRAFIA E ESTATÍSTICA. Recenseamento de 1920. $4 \circ$ Censo geral da população e $1^{\circ}$ da agricultura e das indústias. 1927. Available at:

https://biblioteca.ibge.gov.br/visualizacao/livros/liv6478.pdf. Accessed on: 15 August 2021.

IBGE - INSTITUTO BRASILEIRO DE GEOGRAFIA E ESTATÍSTICA. Recenseamento geral do Brasil. $1^{\circ}$ de Setembro de 1940. Censo demográfico. População e habitação. Quadros de totais para o conjunto da União e de distribuição pelas regiões fisiográficas e unidades federais. Série nacional, v. 2. 1950. Available at: https://biblioteca.ibge.gov.br/visualizacao/periodicos/65/cd_1940_v2_br.pdf. Accessed on: 15 August 2021.

IBGE - INSTITUTO BRASILEIRO DE GEOGRAFIA E ESTATISTICA, 1956. Censo demográfico. Série nacional, v. 1. Available at: https://biblioteca.ibge.gov.br/visualizacao/periodicos/67/cd_1950_v1_br.pdf. Accessed on: 15 August 2021.

IOM - INTERNATIONAL ORGANIZATION FOR MIGRATION. World Migration Report 2018. UN, New York: International Organization for Migration, 2018. p. 2, 19, 68, 70. DOI https://doi.org/10.18356/f45862f3-en

JUST, Marcel A.; CARPENTER, Patricia A. A capacity theory of comprehension: Individual differences in working memory. Psychological Review, v. 99, p.122-149, 1992. DOl https://doi.org/10.1037/0033-295x.99.1.122

KEMPLER, Daniel; ALMOR, Amit; TYLER, Lorraine K.; ANDERSEN, Elaine S.; MACDONALD, Maryellen C. Sentence comprehension deficits in Alzheimer's disease: a comparison of off-line vs. on-line sentence processing. Brain and Language, v. 64, n. 3, p. 297-316, 1998. DOI https://doi.org/10.1006/brln.1998.1980

KORMOS, Judit; TREBITS, Anna. Working memory capacity and narrative task performance. In: ROBINSON, Peter. (Ed.). Second Language Task Complexity:Researching the Cognition Hypothesis of language learning and performance. Amsterdam: John Benjamins Publishing Company, 2011. p. 267-286. DOI https://doi.org/10.1075/tblt.2

KRAMER, Rossana; MOTA, Mailce Borges. Effects of bilingualism on inhibitory control and working memory: a study with early and late bilinguals. Gragoatá, v. 20, n. 38, p. 309-331, 2015. Available at: https://periodicos.uff.br/gragoata/article/view/33312. Accessed on: 13 August 2021.

LEHTONEN, Minna: SOVERI, Anna: LAINE, Aini; JARVENPAA, Janica; DE BRUIN, Angela; ANTFOLK, Jan. Is bilingualism associated with enhanced executive functioning in adults? A meta-analytic review. Psychological Bulletin, v. 144, n. 4 p. 394-425, 2018. DOI https://doi.org/10.1037/bul0000142

LUKASIK, Karolina M.; LEHTONEN, Minna; SOVERI, Anna; WARIS, Otto; JYLKKA, Jussi; LAINE, Matti. Bilingualism and working memory performance: Evidence from a large-scale online study. PLOS ONE, v. 13, n. 11, 2018. DOI https://doi.org/10.1371/journal.pone.0205916

MARIAN, Viorica; BLUMENFELD, Henrike K.; KAUSHANSKAYA, Margarita. The Language Experience and Proficiency Questionnaire (LEAP-Q): Assessing language profiles in bilinguals and multilinguals. Journal of Speech, Language, and Hearing Research, v. 50, n. 4, p. 940-967, 2007. DOI https://doi.org/10.1044/1092-4388(2007/067)

MASCARELLO, Lidiomar José. Memória de trabalho: que importância tem na aprendizagem e no processamento da linguagem? Working papers in Linguística, v. 13, n. 3, p. 87-105, 2012. DOI https://doi.org/10.5007/1984$8420.2012 v 13 n 3 p 87$

MATIELO, Rafael; OLIVEIRA, Roberta Pires de; BARETTA, Luciane. Subtitling, Working Memory, and L2 Learning: A Correlational Study. Revista brasileira de linguística aplicada, v. 18, n. 3, p. 665-696, 2018. DOI http://dx.doi.org/10.1590/1984-6398201812773

MILESKI, Ivanete. Variação no português de contato com o polonês no Rio Grande do Sul: vogais médias tônicas e pretônicas. 321 p. Thesis (PhD in Language Studies) - Faculdade de Letras, Pontifícia Universidade Católica do Rio Grande do Sul, Porto Alegre, 2017. Available at: http://tede2.pucrs.br/tede2/handle/tede/7794. Accessed on: 13 August 2021

MONTRUL, Silvina. The Acquisition of Heritage Languages. Cambridge: Cambridge University Press, 2015. p. 41-89

MOTA, Mailce Borges. Working memory capacity and fluency, accuracy, complexity, and lexical density in L2 speech production. Fragmentos, v. 24, p. 69-104, 2003. Available at:

https://periodicos.ufsc.br/index.php/fragmentos/article/view/7659. Accessed on: 15 August 2021. 
NAWA, Takako. Bilingüismo e mudança de código: uma proposta de analise com os nipo-brasileiros residentes em Brasília. 144 p. 1988. Dissertation (Master's degree in Linguistics) - Departamento de Linguística, Instituto de Comunicação e Expressão, Universidade de Brasília, Brasília. Available at: https://repositorio.unb.br/handle/10482/12074. Accessed on: 13 August 2021

ORTIZ-PREUSS, Elena. Psicolinguística do bilinguismo: implicações em processos formais de acquisição de línguas I/ha do Desterro, v. 72, n. 3, p. 291-309, 2019. DOI https://doi.org/10.5007/2175-8026.2019v72n3p291

OSAKA, Mariko; OSAKA, Naoyuki. Language-independent working memory as measured by Japanese and English reading span tests. Bulletin of the Psychonomic Society, v. 30, p. 287-289, 1992. DOI https://doi.org/10.3758/BF03330466

OSAKA, Mariko; OSAKA, Naoyuki; GRONER, Rudolf. Language independent working memory: Evidence from German and French reading span tests. Bulletin of the Psychonomic Society, v. 31, p. 117-118, 1993. DO https://doi.org/10.3758/BF03334156

PARADIS, Michel. On the representation of two languages in one brain. Language Science, n. 7, p. 1-39, 1985. DOI https://doi.org/10.1016/S0388-0001(85)80010-3

PISKE, Thorsten; MACKAY, lan R. A.; FLEGE, James Emil. Factors affecting degree of foreign accent in an L2: a review. Journal of Phonetics, v. 29, p. 191-215, 2001. DOI https://doi.org/10.006/ipho.2001.0134

POLINSKY, Maria; KAGAN, Olga. Heritage languages: In the 'Wild' and in the Classroom. Language and Linguistics Compass, v. 1, n. 5, p. 368-395, 2007. DOl https://doi.org/10.1111/i.1749-818X.2007.00022.x

PORTES, Alejandro; HAO, Lingxin. E Pluribus Unum: Bilingualism and Loss of Language in the Second Generation Sociology of Education, v. 71, n. 4, p. 269-294, 1998. DOl https://doi.org/10.2307/2673171.

POULISSE, Nanda. A theoretical account of lexical communication strategies. In: SCHREUDER, Robert.; WELTENS, Bert (Eds.). The bilingual lexicon. Amsterdam: John Benjamins, 1993. p. 157-189.

PREBIANCA, Gicele Vergine Vieira; FINARDI, Kyria Rebeca; WEISSHEIMER, Janaina. Working Memory Capacity Across L2 Speech Proficiency Levels. Revista Brasileira de Linguística Aplicada, v. 14, n. 2, p. 441-462, 2014. DOI http://doi.org/10.1590/S1984-63982014005000009

QUINTINO, Felipe; TONHATI, Tânia. Uma análise das autorizações de trabalho concedidas a estrangeiros pela Coordenação Geral de Imigração (CGlg 2011-2016). In: CAVALCANTE, Leonardo; TADEU DE OLIVEIRA, Antônio; ARAUJO, Dina; TONHATI, Tânia. (Orgs.). A inserção dos imigrantes no mercado de trabalho brasileiro. Relatório anual 2017. Série Migrações. Observatório das Migrações Internacionais; Ministério do Trabalho/ Conselho Nacional de Imigração e Coordenação Geral de Imigração. Brasília, DF: OBMigra, 2017, p. 16-33.

RUSEISHVILI, Svetlana. Ser russo em São Paulo. Os imigrantes russos e a reformulação de identidade após a Revolução Bolchevique de 1917. 383 p. Thesis (PhD in Social Studies) - Faculdade de Filosofia, Letras e Ciências Humanas, Universidade de São Paulo, São Paulo, 2016. Available at: https://teses.usp.br/teses/disponiveis/8/8132/tde-13022017-124015/pt-br.php. Accessed on: 13 August 2021.

RUSEISHVILI, Svetlana. Perfil sociodemográfico e distribuição territorial dos russos em São Paulo: deslocados de guerra da Europa e refugiados da China após a Segunda Guerra Mundial. Revista Brasileira de Estudos de População, v. 35, n. 2, 2018, p. 1-20. DOl https://doi.org/10.20947/S0102-3098a0036

RUSEISHVILI, Svetlana. Entre o campo e a cidade: a mobilidade dos imigrantes bessarábios em São Paulo na primeira metade do século XX. In:TRUZZI, Oswaldo (Org.). Migrações Internacionais no Interior Paulista: contexto, trajetórias e associativismo (1880-1950). São Carlos: EdUFSCar. In press.

SEVINC, Yesim. Language maintenance and shift under pressure: Three generations of the Turkish immigrant community in the Netherlands. International Journal of the Sociology of Language, v. 2016, n. 242, p. 81-117, 2016. DOI https://doi.org/10.1515/ijsl-2016-0034.

SIMONET, Miquel. Phonetic behavior in proficient bilinguals: Insights from the Catalan-Spanish Contact Situation. In: GIBSON, Mark; GIL, Juana. (Eds.). Romance Phonetics and Phonology. Oxford: Oxford University Press, 2019. p. 395406 .

SISMIGRA - SISTEMA DE REGISTRO NACIONAL MIGRATÓRIO. Banco Interativo do Observatório das Migrações em São Paulo - NEPOUNICAMP - CNPq/MPT. Available at: https://www.nepo.unicamp.br/observatorio/bancointerativo/. Accessed on: 15 August 2021. 
SMIRNOVA HENRIQUES, Anna; BARROS, Thaiza; MADUREIRA, Sandra. Proficiência oral em Português Brasileiro: cenário, contextos de avaliação e de instrução e questionamentos. Revista da ABRALIN, v. 19, n. 3, p. 775-798, 2020. DOI https://doi.org/10.25189/rabralin.v19i3.1755

SMIRNOVA HENRIQUES, Anna; FONTES, Mario A. de S.; SKRELIN, Pavel A.; KACHKOVSKAIA, Tatiana V.; RUSEISHVILI, Svetlana: BORREGO, Mario C.: PICCIN BERTELLI ZULETA, Patrícia: PICCOLOTTO FERREIRA, Léslie; MADUREIRA, Sandra. Russian immigrants in Brazil: to understand, to be understood. Cadernos de Linguística, v. 1, n. 2, p. 1-18, 2020. DOI https://doi.org/10.25189/2675-4916.2020.v1.n2.id210

SMIRNOVA HENRIQUES, Anna; RUSEISHVILI, Svetlana. Migrantes russófonos no Brasil no século XXI: perfis demográficos, caminhos de inserção e projetos migratórios. Ponto-e-Vírgula, n. 25, p. 83-96, 2020. DOI https://doi.org/10.23925/1982-4807.2019i25p83-96

SMIRNOVA HENRIQUES, Anna: SKOROBOGATOVA, Aleksandra: RUSEISHVILI, Svetlana: SKRELIN, Pavel A.; KACHKOVSKAIA, Tatiana V.; GAGARINA, Natalia; MADUREIRA, Sandra; SEKERINA, Irina A. BraPoRus, ustnyi korpus russkogo jazyka kak unasledovannogo: osobennosti rechi pozhilyh russko-portugal'skih bilingvov v Brazilii [BraPoRus, spoken corpus of heritage Russian: characterization of speech produced by elderly Russian-Portuguese bilinguals in Brazil]. In: THE 9 $^{\text {TH }}$ INTERDISCIPLINARY SEMINAR CONVERSATIONAL RUSSIAN SPEECH ANALYSIS, 2021, Saint Petersburg. Annals [...]. Saint Petersburg: Saint Petersburg State University, Izdatel'stvo Skifiia-print, 2021. p. 87-91. Available at: https://drive.google.com/file/d/1_70u6XLeMGbe-IcOeoYn17R6JrTB3wau/view. Acessed on: 13 August 2021.

SMIRNOVA HENRIQUES, Anna; SKRELIN, Pavel A.; EVDOKIMOVA, Vera V.; KACHKOVSKAIA, Tatiana. V.; BORREGO, Maria Cristina: PICCOLOTTO FERREIRA, Léslie; PICCIN BERTELLI ZULETA, Patrícia.; RUSEISHVILI, Svetlana; MADUREIRA, Sandra. The perception of Brazilian Portuguese open and close mid vowels by native Russian speakers. JoSS, v. 8, n. 2, p. 59-84, 2019. DOI https://doi.org/10.20396/joss.v8i2.14995

STANGROOM, J. Social Science Statistics, Statistics Calculators. Available at: https://www.socscistatistics.com/tests/. Accessed on: 15 August 2021.

TESSMANN BANDEIRA, Marta Helena. Comparacão entre o desempenho de criancas bilíngues e monolíngues em tarefas envolvendo a memória de trabalho. In: VIII ENCONTRO DO CENTRO DE ESTUDOS LINGÜÍSTICOS DO SUL (CELSUL), 2008, Porto Alegre. Annals [...]. Porto Alegre: CELSUL, 2008. Available at: http://www.leffa.pro.br/tela4/Textos/Textos/Anais/CELSUL_VIII/comparacao_bilingues_monolingues.pdf. Accessed on: 15 August 2021

TREFFERS-DALLER, Jeanine. Operationalizing and measuring language dominance. International Journal of Bilingualism, v. 15, n. 2, p. 147-163, 2011. DOI https://doi.org/10.1177/1367006910381186

TSIMPLI, Ianthi Maria; ANDREOU, Maria; AGATHOPOULOU, Eleni.; MASOURA, Elvira. Narrative production, bilingualism and working memory Capacity: a study of Greek-German bilingual children. In: KOTZOGLOU, George et al. (Eds.). Selected Papers of the 11th International Conference on Greek Linguistics. Rhodes: University of the Aegean, 2014. p. 1730-1742. Available at: http://ikee.lib.auth.gr/record/269832/files/ICGL_11_selected_papers.pdf. Accessed on: 13 August 2021.

TSIMPLI, lanthi Maria: PERISTERI, Eleni; ANDREOU, Maria Narrative production in monolingual and bilingual children with specific language impairment. Applied Psycholinguistics, v. 37, n. 1, p. 195-216, 2016. DOI https://doi.org/10.1017/S0142716415000478

VEJNOVIC, Dusan; MILIN, Petar; ZDRAVKOVIĆ, Suncica. Effects of proficiency and age of language acquisition on working memory performance in bilinguals. Psihologija, v. 43, n. 3, p. 219-232, 2010. DOI https://doi.org/10.2298/PSI1003219V

VOROBIEFF Alexandre Identidade e memória da comunidade russa na cidade de São Paulo. 244 p. Dissertation (Master's degree in Human Geography) - Departamento de Geografia, Faculdade de Filosofia, Letras e Ciências Humanas, Universidade de São Paulo, São Paulo, 2006. Available at:

https://teses.usp.br/teses/disponiveis/8/8136/tde-18062007-141410/pt-br.php. Accessed on: 13 August 2021.

VOROBYEVA, Olga; ALESHKOVSKI, Ivan; GREBENYUK, Alexander. Russian Emigration at the Turn of the 21st Century. Filosofija. Sociologiia, v. 29, n. 2, p. 107-118, 2018. DOI https://doi.org/10.6001/fil-soc.v29i2.3706

WEISSHEIMER, Janaina; MOTA, Mailce Borges. Individual Differences in Working Memory Capacity and the Development of L2 Speech Production. Issues in applied linguistics, v. 17, n. 2, p. 93-122, 2009. DOI https://doi.org/10.5070/L4172005115 
XUE, Gui; DONG, Qi; JIN, Zhen; CHEN, Chuansheng. Mapping of verbal working memory in nonfluent Chinese-English bilinguals with functional MRI. Neurolmage, v. 22, n. 1, p. 1-10, 2004. DOI https://doi.org/10.1016/i.neuroimage.2004.01.013

YOUSE, Kathleen M.; COELHO, Carl A. Working memory and discourse production abilities following closed-head injury. Brain injury, v. 19, n. 12, p. 1001-1009, 2005. DOI https://doi.org/10.1080/02699050500109951

ZIMMER, Márcia C.; FINGER, Ingrid; SCHERER, Lilian. Do bilingüismo ao multilingüismo: intersecções entre a psicolingüística e a neurolingüística. ReVEL, v. 6, n. 11, 2008. Available at:

http://www.revel.inf.br/files/artigos/revel_11_do_bilinguismo_ao_multilinguismo.pdf. Accessed on: 13 August 2021. 